\title{
PENGARUH EKSTRAK PROPOLIS TERHADAP EKSPRESI CYCLIN D1 DAN BAX PADA SEL HELA
}

\section{EFFECT OF PROPOLIS EXTRACT TOWARD CYCLIN D1 AND BAX EXPRESSION ON HELA CELL LINE}

\author{
Irma Febrina, Suradi Maryono, Bambang Purwanto \\ Sub Bagian Hemato Onkologi Medik, Bagian Ilmu Penyakit Dalam \\ FK UNS / RSUD Dr. Moewardi Surakarta \\ Korespondensi: dr. Irma Febrina Sp. PD. Email: irmafebrina@yahoo.co.id
}

\begin{abstract}
ABSTRAK
Kanker serviks merupakan kanker ginekologi tertinggi di dunia dengan infeksi Human Papilloma Virus sebagai penyebab terseringnya. Di Indonesia, kanker serviks merupakan keganasan yang paling banyak ditemukan dan penyebab kematian utama pada perempuan dalam tiga dasawarsa terakhir. Di Indonesia, setiap tahun terdeteksi lebih dari 15.000 kasus kanker serviks dan sekitar 8.000 kasus di antaranya berakhir dengan kematian. Terdapat beberapa jenis pengobatan yang biasa diberikan pada penderita kanker serviks, namun hasilnya relatif belum optimal. Keadaan ini mendorong usaha penemuan dan pengembangan strategi terapi baru dalam melawan kanker. Pendekatan yang menarik untuk dikembangkan adalah penggunaan kombinasi kemoterapi atau ko-kemoterapi. Ko-kemoterapi merupakan strategi terapi kanker dengan mengombinasikan suatu senyawa kemopreventif yang bersifat tidak toksik dengan agen kemoterapi. Salah satu produk natural yang potensial untuk dikembangkan sebagai agen ko-kemoterapi adalah propolis. Penelitian ini bertujuan untuk mengetahui pengaruh pemberian propolis yang berasal dari Kerjo, Karanganyar, Indonesia terhadap induksi proses apoptosis dan aktivitas antiproliferasi, terutama terkait dengan penekanan ekspresi protein Cyclin D1 dan peningkatan ekspresi protein Bax pada kultur sel HeLa (cell line kanker serviks). Penelitian ini merupakan penelitian eksperimental laboratorik dengan menggunakan post test with control group design. Penelitian dilakukan pada kultur sel HeLa (sel kanker serviks) dengan pemberian propolis. Pengamatan ekspresi protein Cyclin D1 dan ekspresi protein Bax dilakukan dengan metode imunositokimia. Hasil penelitian menemukan bahwa ekspresi rata-rata Cyclin D1 pada kelima kelompok yaitu kontrol 84,13 $\pm 1,34 \mu \mathrm{g} / \mathrm{ml}$, EEP $1 / 2 \mathrm{IC}_{50} 60,76 \pm 4,21$, EEP IC $\mathrm{I}_{50} 36,56 \pm 3,63 \mu \mathrm{g} / \mathrm{ml}$, EEP $2 \mathrm{IC}_{50}$ $24,92 \pm 5,14 \mu \mathrm{g} / \mathrm{ml}, 5-\mathrm{FU} 13,15 \pm 3,66 \mu \mathrm{g} / \mathrm{ml}$. Terdapat perbedaan bermakna ekspresi Cyclin D1 antara kelompok perlakuan dibandingkan kelompok kontrol $(\mathrm{p}<0,001)$. Rata-rata ekspresi Bax pada kelima kelompok yaitu kontrol $1,89 \pm 0,46 \mu \mathrm{g} / \mathrm{ml}$, EEP $1 / 2 \mathrm{IC}_{50} 69,44 \pm 1,39$, EEP IC ${ }_{50} 80,07 \pm 3,52 \mu \mathrm{g} / \mathrm{ml}$, EEP $2 \mathrm{IC}_{50} 83,96 \pm 3,26 \mu \mathrm{g} / \mathrm{ml}, 5-\mathrm{FU}$ $92,78 \pm 4,68 \mu \mathrm{g} / \mathrm{ml}$. Terdapat perbedaan bermakna ekspresi Bax antara kelompok uji dibandingkan kelompok kontrol $(p<0,001)$. Penelitian ini menyimpulkan bahwa pemberian ekstrak etanol propolis mempunyai pengaruh terhadap penekanan ekspresi Cyclin D1 dan peningkatan ekspresi Bax pada kultur sel kanker serviks (HeLa Cell line).
\end{abstract}

Kata kunci: EEP, Protein Cyclin D1, Protein Bax, HeLa cell line

\section{ABSTRACT}

Cervical cancer is the highest gynecological cancer in the world with Human Papilloma Virus infection as the most common cause. In Indonesia, cervical cancer is the most common malignancy and the leading cause of death in women in the last three decades. In Indonesia, every year more than 15,000 cases of cervical cancer are detected and about 8,000 of them end in death. There are several types of treatment usually given for cervical cancer patient, but the results were relatively not optimal. This situation encourages the discovery and development of new therapeutic strategies in combating cervical cancer. An interesting approach to develop is the use of a combination of chemotherapy or co-chemotherapy. Co-chemotherapy is a cancer therapeutic strategy by combining a nontoxic chemopreventive compound with a chemotherapeutic agent. One potential natural product to be developed as a co-chemotherapy agent is propolis. This study aimed to determine the effect of propolis administration from Kerjo, Karanganyar, Indonesia to induction of apoptotic process and anti proliferative activity, mainly related to suppression of Cyclin D1 protein expression and increased expression of Bax protein on cell culture of cervical 
cancer. This study was a laboratory experimental research using post test with control group design. This study was conducted on cell culture HeLa (cervical cancer cells) with propolis administration. Observations of Cyclin D1 protein and Bax protein expression were performed by immunocytochemical methods. The results showed that the average expression of Cyclin D1 in the five groups was control group $84.13 \pm 1.34 \mu \mathrm{g} / \mathrm{ml}$, EEP 1/2 IC50 $60.76 \pm 4.21$, EEP IC50 $36.56 \pm 3.63 \mu \mathrm{g} / \mathrm{ml}$, EEP 2 IC50 $24.92 \pm 5.14 \mu \mathrm{g} / \mathrm{ml}, 5-F U 13.15 \pm 3.66 \mu \mathrm{g} / \mathrm{ml}$. There were significant differences in Cyclin D1 expression between treatment groups versus control group $(p<0.001)$. The average of Bax expression in the five groups was $1.89 \pm 0.46 \mu \mathrm{g} / \mathrm{ml}$ control, EEP 1/2 IC50 $69.44 \pm 1.39$, EEP IC50 $80.07 \pm 3.52 \mu \mathrm{g} / \mathrm{ml}$, EEP 2 IC50 83, $96 \pm 3.26 \mu \mathrm{g} / \mathrm{ml}, 5-F U 92.78 \pm 4.68 \mu \mathrm{g} / \mathrm{ml}$. There was a significant difference in Bax expression between the test groups versus the control group $(p<0.001)$. This study concluded that administration of ethanol propolis extract has an effect on Cyclin D1 expression suppression and increased Bax expression on cervical cancer cell culture (HeLa Cell line).

Keywords: EEP, Cyclin D1 protein, Bax protein, HeLa cell line

\section{PENDAHULUAN}

Kanker merupakan penyebab kematian utama, baik di negara maju maupun negara berkembang. Di Indonesia, kanker menjadi masalah kesehatan di masyarakat dengan prevalensi 4,3 per 1000 penduduk dan menjadi penyebab kematian kelima setelah stroke, tuberculosis, diabetes mellitus, dan trauma kepala (Depkes RI, 2009). Keganasan hematologi, termasuk leukemia, limfoma, dan myeloma, merupakan sekitar 9\% dari semua kasus baru kanker yang paling sering didiagnosis di negaranegara berkembang (Molyneux et al ,2012).

Salah satu jenis keganasan yang ditemukan di Indonesia adalah kanker serviks. Kanker serviks merupakan kanker ginekologi tertinggi di dunia dengan penyebab tersering infeksi Human Papilloma Virus (HPV) (Hutchinson dan Klein, 2008). Di Indonesia, kanker serviks merupakan keganasan yang paling banyak ditemukan dan penyebab kematian utama pada perempuan dalam tiga dasawarsa terakhir. Diperkirakan insiden penyakit ini sekitar 100 per 100.000 penduduk (Azis, 2001).

Terdapat beberapa jenis pengobatan yang biasa diberikan pada penderita kanker serviks, namun hasilnya relatif belum optimal. Terapi pembedahan bersifat terbatas karena hanya dapat diterapkan pada penderita kanker serviks stadium awal dan penderita usia muda yang telah kehilangan fertilitasnya, sedangkan radioterapi dan kemoterapi sering menimbulkan efek samping yang berat (Fujimoto, 2009). Kemoterapi didasarkan pada kerusakan DNA sehingga menyebabkan kematian sel baik melalui apoptosis maupun nekrosis (Hakem dan Harrington, 2005). Kemoterapi belum memberikan hasil yang optimal dan sering menimbulkan efek samping yang serius karena pada umumnya tidak bekerja secara spesifik pada sel kanker tetapi juga pada sel normal (Goldie, 2001). Keadaan ini mendorong usaha penemuan dan pengembangan strategi terapi yang baru dalam melawan kanker.

Sejumlah penelitian telah menunjukkan bahwa peningkatan konsumsi diet nabati yang teratur dapat mengurangi risiko kanker. Oleh karena itu, banyak studi yang saat ini difokuskan pada temuan senyawa bioaktif baru dari sumber alami dan sejumlah besar produk alami yang telah dievaluasi mempunyai potensi kemopreventif (Lin CC et al., 2012).

Pendekatan yang menarik untuk dikembangkan adalah penggunaan kombinasi kemoterapi atau sering disebut sebagai kokemoterapi. Ko-kemoterapi merupakan strategi terapi kanker dengan mengkombinasikan suatu senyawa kemopreventif yang bersifat tidak toksik dengan agen kemoterapi. Hal ini dapat meningkatkan efikasi agen kemoterapi karena adanya kombinasi yang sinergis dan memperkecil kemungkinan efek samping karena mengurangi dosis agen kemoterapi (Alison, 2004).

Aplikasi ko-kemoterapi merupakan salah satu modalitas yang paling menjanjikan dalam penelitian onkologi yang berfokus pada pencegahan kanker dengan menggunakan produk alami atau sintetis agen alami yang menghambat proses karsinogenesis (Naithani et al., 2008).

Salah satu produk natural yang potensial untuk dikembangkan sebagai agen ko-kemoterapi adalah propolis. Propolis telah lama dikenal dan digunakan sebagai obat tradisional yang memiliki berbagai efek menguntungkan meliputi antibakteri, antifungi, antivirus, imunostimulator, dan antikanker (Bancova, 2007).

Propolis terdiri dari campuran resin, serbuk 
sari, dan lilin tanaman yang dikumpulkan lebah dari berbagai jenis tanaman dan digunakan untuk proteksi sarang lebah dari mikroba (Ananda et al., 2013; Watanabe et al., 2011).

Secara umum, kandungan propolis adalah asam lemak, asam alifatik, asam aromatik, flavonoid, alkohol, terpene, gula, dan ester. Komposisi senyawa kimiawi dan aktivitas biologi propolis bervariasi tergantung lokasi geografi, asal tanaman, musim, dan spesies lebah (Paulino et al., 2009).

Propolis adalah suatu zat yang dihasilkan oleh lebah madu, mengandung resin dan lilin lebah, bersifat lengket yang dikumpulkan dari sumber tanaman, terutama dari bunga dan pucuk daun, untuk kemudian dicampur dengan air liur lebah (Marcucci et al., 2001, Salatino et al., 2005; Nakajima et al., 2009).

Propolis telah dibuktikan mempunyai berbagai aktivitas biologis seperti antibakteri, antijamur, antivirus, anestetik lokal, antiinflamasi, antioksidan, hepatoprotektor, imunostimulator,serta berperan pada proses penyembuhan luka (Paulino et al., 2009 ; Vatansever et al., 2010 ; Kubina et al., 2015).

Propolis terdiri dari campuran resin, serbuk sari dan lilin tanaman yang dikumpulkan lebah dari berbagai jenis tanaman dan digunakan untuk proteksi sarang lebah dari mikroba (Ananda et al., 2013; Watanabe et al., 2011).

Propolis mengandung berbagai senyawa kimiawi, seperti polyphenol (flavanoids, asam fenolat dan esternya, aldehid fenolat, alcohol, dan keton), terpenoid, steroid, asam amino, dan berbagai komponen inorganik (Kartal et al. 2003).

Komposisi senyawa kimiawi dan aktivitas biologi propolis bervariasi tergantung lokasi geografi, asal tanaman, musim, dan spesies lebah (Paulino et al., 2009, Syamsudin et al., 2009).

Salah satu hal yang menjanjikan dari propolis, yaitu terkait dengan aktivitas antikanker yang dimilikinya. Peran propolis di dalam terapi keganasan terkait dengan kemampuannya dalam aktivitas antiproliferasi dan menginduksi apoptosis. Pada berbagai penelitian in vitro propolis menunjukkan aktivitas antikanker pada berbagai jenis sel kanker, meliputi: kanker laring, kanker paru, kanker pankreas, kanker thyroid, kanker kolorektal, kanker payudara, kanker prostat, dan glioma (Kubina et al., 2015).

Sel HeLa adalah sel yang berasal dari sel kanker serviks yang diambil dari seorang penderita kanker serviks bernama Henrietta Lacks. Sel ini bersifat produktif sehingga banyak digunakan dalam penelitian ilmiah (Watts dan Denise, 2010).

Sel HeLa bersifat produktif karena mampu melakukan proliferasi relatif cepat dibandingkan dengan sel kanker lainnya. Sel ini memiliki telomerase yang aktif selama pembelahan sel sehingga mencegah pemendekan telomer yang terkait dengan penuaan dan kematian sel (Sharrer, 2006). Selain itu sebagian besar sel kanker serviks, termasuk sel HeLa mempunyai gen $\mathrm{p} 53$ dan $\mathrm{p} 105 \mathrm{Rb}$ dalam bentuk wild type, tetapi aktivitasnya dihambat oleh ekspresi protein E6 dan E7 dari HPV tipe high-risk (Goodwin dan DiMaio, 2000).

Sel HeLa digunakan pada penelitian ini karena relatif cepat membelah, merepresentasikan sel kanker serviks yang disebabkan infeksi HPVtipe high-risk dan memiliki p53 dalam bentuk wild type.

Di samping itu, jalur Wnt/ $\beta$-catenin merupakan salah satu kandidat jalur sinyal pada kanker serviks. Penanda penting pada jalur ini adalah adanya aktivasi $W n t$ yang menyebabkan stabilisasi $\beta$-catenin di sitoplasma dan akumulasi $\beta$-catenin di nukleus. Akumulasi ini mengakibatkan aktivasi gen-gen target seperti gen yang berperan pada ekspresi $c-m y c$ dan cyclin D1 yang terlibat pada proses proliferasi sel dan progresivitas siklus sel (Plasencia, 2008).

DVL3 merupakan onkoprotein yang berperan pada aktivasi jalur $W n t / \beta$-catenin pada kanker serviks. Aktivator AMPK termasuk metformin terbukti mampu menyebabkan downregulation DVL3 sehingga menekan ekspresi $\beta$-catenin dan cyclin D1. Hal ini selanjutnya akan mengganggu proses proliferasi sel (Kwan et al., 2012).

Berdasarkan fakta-fakta yang diuraikan di atas, mendorong peneliti untuk mengetahui pengaruh pemberian propolis yang berasal dari Kerjo, Karanganyar, Indonesia terhadap aktivitas anti kanker, terkait dengan ekspresi protein CyclinDl dan Bax serta induksi apoptosis pada kultur sel kanker serviks (HeLa cell line). Penelitian ini sebagai upaya penemuan dan pengembangan strategi baru dalam menangani kanker, khususnya kanker limfoma dengan memanfaatkan kekayaan hayati lokal. 


\section{METODE PENELITIAN}

Penelitian ini merupakan penelitian eksperimental laboratorik dengan menggunakan post test with control group design. Penelitian dilakukan pada kultur sel HeLa (sel kanker serviks) dengan pemberian ekstrak etanol propolis dan cisplatin sebagai kontrol positif. Pengamatan ekspresi protein Cyclin D1 dan Bax dilakukan dengan metode imunositokimia.

\section{HASIL DAN PEMBAHASAN}

1. Uji sitotoksisitas dengan MTTassay untuk menetapkan nilai $\mathrm{IC}_{50}$ ekstrak etanol propolis dan Cisplatin.

Uji sitotoksistas dilakukan setelah kultur sel siap dipanen, sel HeLa yang ditumbuhkan pada media komplet, selanjutnya diberikan perlakuan dengan senyawa propolis. Sel HeLa yang hidup memiliki morfologi seperti epitel gepeng lonjong dan menempel pada dasar sumuran, sedangkan sel HeLa yang mati berbentuk bulat kecil, tersebar dan tidak menempel pada dasar sumuran. Morfologi sel HeLa ditunjukkan pada Gambar 1.

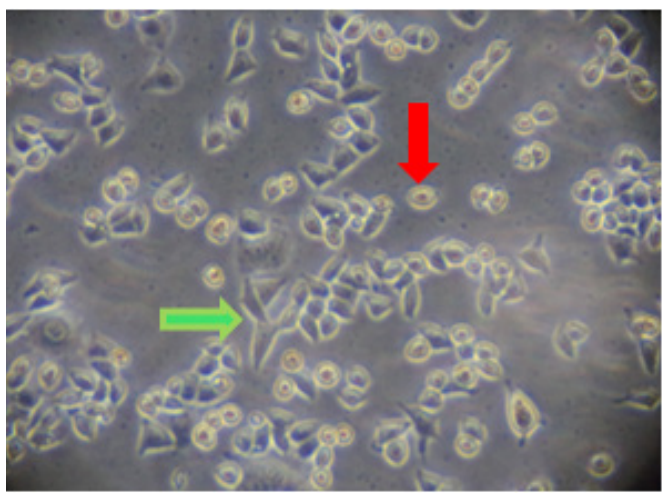

Gambar 1 Morfologi sel HeLa, sel hidup ditunjukkan panah warna hijau dan sel mati ditunjukkan panah warna merah. Sel diamati dengan mikroskop inverted dengan perbesaran 100 kali

Untuk mengetahui aktivitas sitotoksisitas dari senyawa propolis yang diujikan pada sel $\mathrm{HeLa}$ dilakukan dengan menggunakan metode MTT assay. Inkubasi dilakukan selama 24 jam setelah pemberian propolis, kemudian diberi penambahan reagen yellow MTT. Data yang didapatkan dari uji sitotoksisitas dengan MTT assay berupa absorbansi dari tiap sumuran yang merupakan hasil pembacaan dengan ELISA reader pada panjang gelombang $595 \mathrm{~nm}$.

Data tersebut kemudian diolah lebih lanjut dengan cara membandingkan nilai absorbansi antara sel yang diberi perlakuan dan kontrol (sel tanpa perlakuan) setelah masing-masing dikurangi dengan kontrol media (blank). Data tersebut digunakan untuk menetapkan nilai $\mathrm{IC}_{50}$ bahan uji dengan menggunakan analisis regresi linear antara dosis bahan uji dan persentase viabilitas sel HeLa. Nilai rata-rata persentase viabilitas sel HeLa dan $\mathrm{IC}_{50}$ dari bahan uji ditunjukkan pada Tabel 1.

Tabel 1 Nilai rata-rata persentase viabilitas sel HeLa dan nilai $\mathrm{IC}_{50}$ bahan uji dengan metode MTT assay.

\begin{tabular}{|c|c|c|c|}
\hline Bahan Uji & $\begin{array}{c}\text { Konsentrasi } \\
(\mu \mathrm{g} / \mathrm{mL})\end{array}$ & $\begin{array}{l}\text { Rata-rata } \\
\text { viabilitas } \\
\text { sel } H e L a \\
(\% \pm \mathrm{SD})\end{array}$ & $\begin{array}{c}\mathrm{IC}_{50} \pm \mathrm{SD} \\
(\mu \mathrm{g} / \mathrm{mL})\end{array}$ \\
\hline \multirow{5}{*}{$\begin{array}{c}\text { Ekstrak } \\
\text { Etanol } \\
\text { Propolis } \\
\text { (EEP) }\end{array}$} & 12,5 & $89,98 \pm 1,97$ & \multirow{5}{*}{$70,42 \pm 1,07$} \\
\hline & 25 & $69,66 \pm 4,41$ & \\
\hline & 50 & $49,22 \pm 1,75$ & \\
\hline & 100 & $19,44 \pm 1,42$ & \\
\hline & 200 & $7,15 \pm 1,26$ & \\
\hline \multirow{5}{*}{ Cisplatin } & 12,5 & $100,63 \pm 18,01$ & \multirow{5}{*}{$45,72 \pm 48,82$} \\
\hline & 25 & $117,42 \pm 8,05$ & \\
\hline & 50 & $109,68 \pm 9,80$ & \\
\hline & 100 & $106,19 \pm 7,38$ & \\
\hline & 200 & $88,55 \pm 5,14$ & \\
\hline
\end{tabular}

Secara umum bahan uji mampu menghambat proliferasi sel HeLa.Hal ini terlihat dari semakin ditingkatkan konsentrasi bahan uji semakin sedikit persentase viabilitas sel HeLa. Aktivitas sitotoksisitas bahan uji ini dinyatakan dengan nilai IC50 yang diperoleh melalui analisis regresi linear antara logaritma konsentrasi bahan uji dengan persentase viabilitas sel HeLa. Dari analisis regresi linear diperoleh IC50 EEP sebesar $70,42 \mathrm{ug} / \mathrm{uL}$. Nilai IC50 EEP ini digunakan sebagai dasar penentuan konsentrasi EEP yang digunakan pada penelitian selanjutnya, yaitu sebesar 35, 70, dan $140 \mathrm{ug} / \mathrm{uL}$ (1/2 IC50, IC50, dan 2 IC50). Nilai IC50 cisplatin akan digunakan sebagai pembanding pada uji apoptosis, yaitu sebesar 45,72 ug/uL.

\section{Pengamatan ekspresi cyclin D1}

Alison pada tahun 2001 menyatakan bahwa cyclin D1 merupakan protein starter untuk mulainya siklus sel. Oleh karena itu, untuk mengetahui apakah penghambatan proliferasi sel $\mathrm{HeLa}$ setelah pemberian EEP selama 24 jam terkait 
penekanan ekspresi cyclin D1, maka dilakukan pengamatan penekanan ekspresi cyclin D1 pada sel HeLa dengan pengecatan imunositokimia.

Pengecatan imunositokimia untuk cyclin D1 dilakukan pada 4 kelompok perlakuan (Kontrol, $1 / 2 \quad \mathrm{IC}_{50} \quad \mathrm{IC}_{50}$ dan $2 \quad \mathrm{IC}_{50}$ ), dan masing-masing kelompok perlakuan tersebut dibuat triplicate.

Data yang diperoleh berupa persentase sel yang mengekspresikan cyclin D1 (tampak sebagai warna coklat pada inti sel maupun sitoplasma) dari keseluruhan sel pada 5 lapangan pandang dan penilaiannya dilakukan pada 3 slide dari tiap-tiap kelompok perlakuan. Hasil pengecatan imunositokimia untuk ekspresi cyclin D1 pada sel HeLa tampak pada Gambar 2 dan grafik hubungan antara konsentrasi ekstrak etanol propolis dengan rata-rata ekspresi cyclin D1 pada sel HeLa dapat dilihat pada gambar 2.
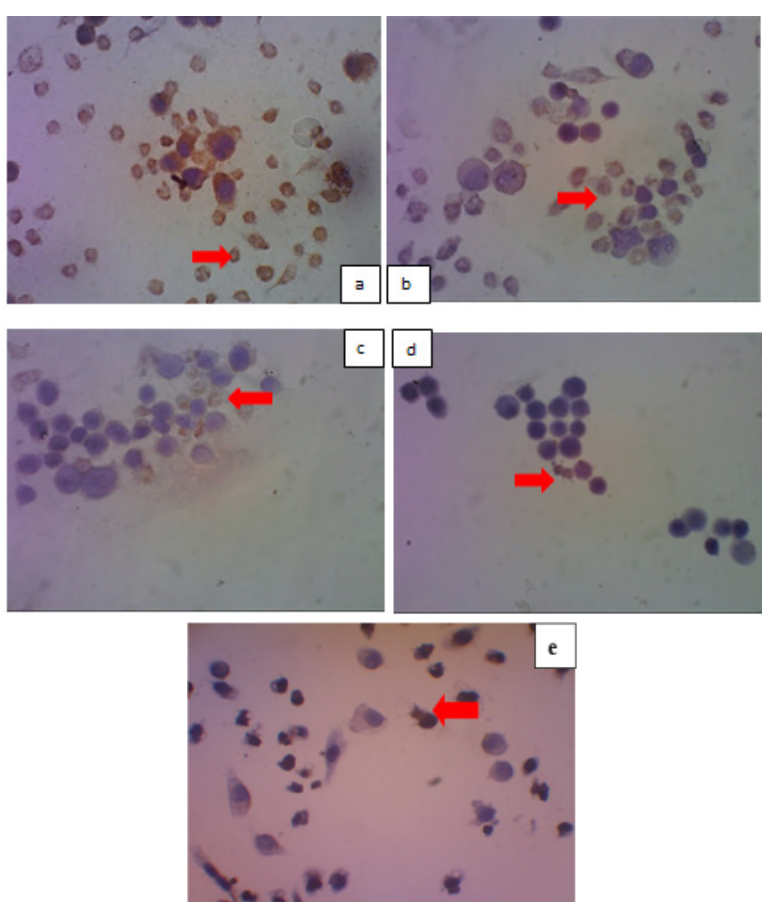

Gambar 2 Hasil pengecatan imunositokimia perbesaran 400 kali untuk ekspresi cyclin D1 pada sel $\mathrm{HeLa}$ setelah perlakuan dan inkubasi selama 24 jam pada kelompok kontrol (a), kelompok dengan EEP konsentrasi $1 / 2 \mathrm{IC}_{50}(\mathrm{~b}), \mathrm{IC}_{50}(\mathrm{c})$, dan $2 \mathrm{IC}_{50}(\mathrm{~d})$, Cisplatin (e). Sel yang mengekspresikan cyclin $\mathrm{D} 1$ ditunjukkan dengan panah warna merah

\section{Ekspresi Cyclin D1}

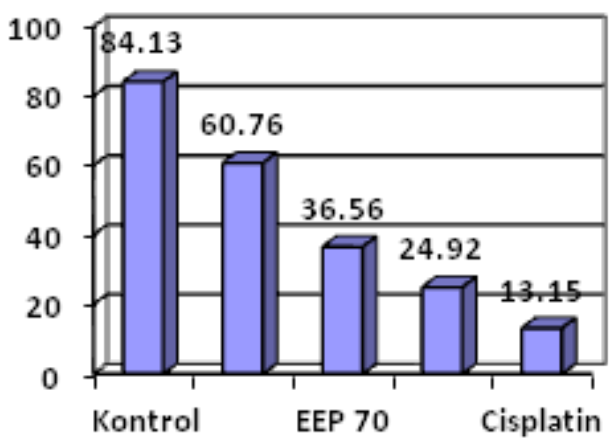

Gambar 3 Grafik hubungan antara konsentrasi EEP dengan rata-rata persentase ekspresi cyclin D1 pada sel HeLa setelah inkubasi 24 jam

Dari grafik di atas, terlihat bahwa pemberian EEP selama 24 jam menekan ekspresi cyclin D1. Penekanan ekspresi cyclin D1 sebanding dengan peningkatan konsentrasi ekstrak etanol propolis yang diberikan. Hasil uji Kruskal-Wallis menunjukkan adanya perbedaan ekspresi cyclin D1 yang bermakna di antara keempat kelompok perlakuan. Hasil multiple comparisons dengan uji Mann whitney menunjukkan bahwa perbedaan ekspresi cyclin D1 yang bermakna terletak di antara semua kelompok perlakuan yang mendapatkan ekstrak etanol propolis dibandingkan dengan kelompok kontrol dan cisplatin dibandingkan dengan kelompok kontrol.

\section{Pengamatan ekspresi protein bax}

Protein bax adalah protein yang diidentifikasi sebagai protein proapoptosis. Peningkatan protein ini mengakibatkan sel lebih sensitif terhadap apoptosis (Dash, 2003). Oleh karena itu, untuk mengetahui apakah peningkatan apoptosis sel HeLa setelah pemberian EEP selama 24 jam terkait peningkatan ekspresi protein bax, maka dilakukan pengamatan peningkatan ekspresi protein bax pada sel HeLa dengan pengecatan imunositokimia.

Pengamatan ini dilakukan dengan pengecatan imunositokimia terhadap bax pada 5 kelompok perlakuan (kontrol, 1/2 IC50, IC50, dan 2 IC50, Cis). Hasil pengecatan imunositokimia untuk bax pada sel HeLa tampak pada Gambar 4. 

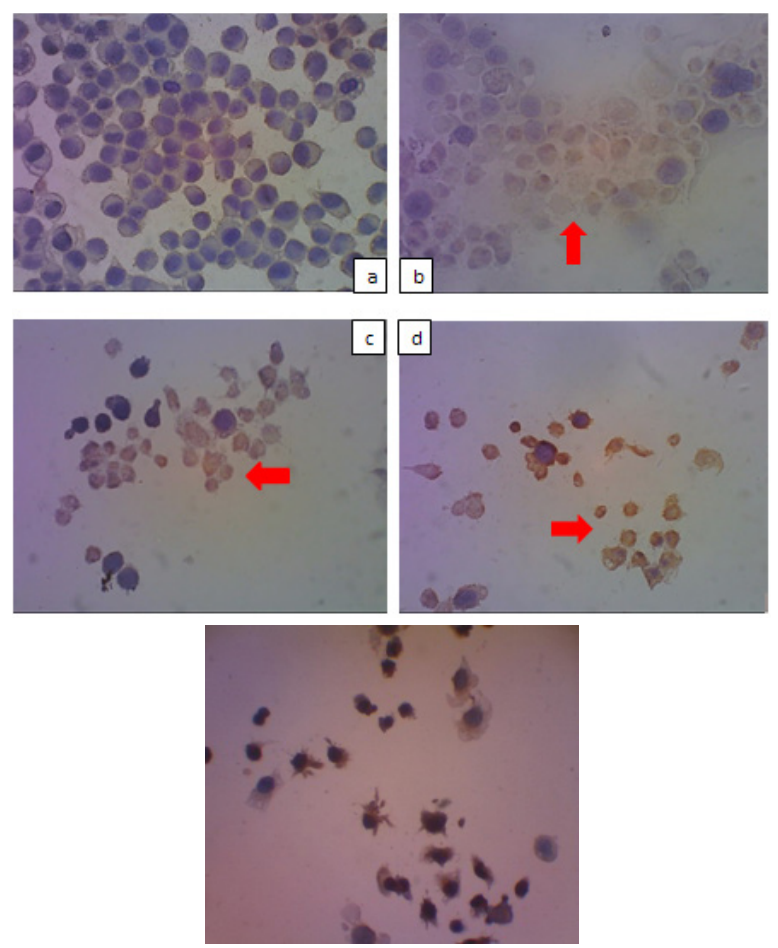

Gambar 4 Hasil pengecatan imunositokimia perbesaran 400 kali untuk ekspresi bax pada sel $\mathrm{HeLa}$ setelah perlakuan dan inkubasi selama 24 jam pada kelompok dengan EEP konsentrasi $1 / 2$ IC50 (a), $\mathrm{IC}_{50}$ (b), 2IC ${ }_{50}$ (c), 5-FU (d) dan kontrol (e). Sel yang mengekspresikan Bax ditunjukkan dengan panah warna merah

\section{Ekspresi Protein Bax [\%]}

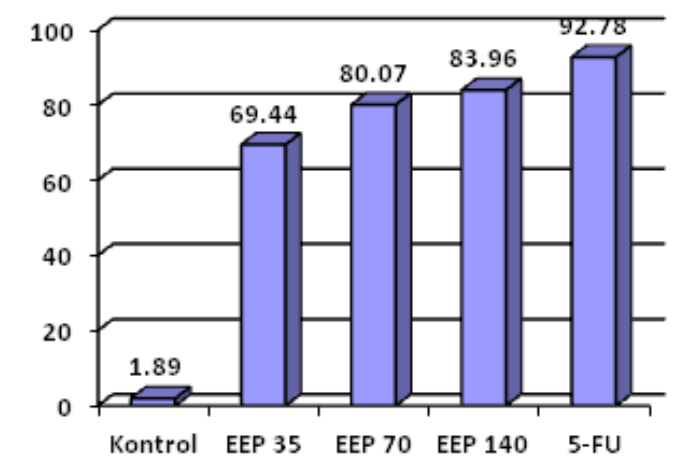

Gambar 7 Hubungan antara konsentrasi bahan uji dengan rata-rata persentase ekspresi protein bax pada sel $H e L a$ setelah inkubasi 24 jam

Dari grafik di atas, terlihat bahwa pemberian propolis selama 24 jam meningkatkan ekspresi Bax. Peningkatan ekspresi Bax sebanding dengan peningkatan konsentrasi ekstrak etanol propolis yang diberikan. Hasil uji statistik menunjukkan adanya perbedaan ekspresi p21 yang bermakna diantara kelima kelompok perlakuan $(\mathrm{p}<0,05)$.

Penelitianinidiawalidenganujisitotoksisitas senyawa ekstrak etanol propolis (EEP) pada sel HeLa menggunakan metode MTT assay. Uji sitotoksisitas ini dilakukan untuk menetapkan nilai IC50 senyawa EEP yang selanjutnya akan digunakan sebagai dasar penetapan konsentrasi EEP untuk pengamatan ekspresi protein cyclin D1, Bax maupun uji induksi apoptosis pada sel HeLa. Selain itu, uji sitotoksisitas ini juga digunakan untuk menetapkan IC50 5-FU pada sel HeLa sebagai kontrol positif pada uji induksi apoptosis.

Pada uji sitotoksisitas ini secara umum didapatkan persentase hambatan proliferasi sel $\mathrm{HeLa}$ semakin meningkat sebanding dengan peningkatan konsentrasi ekstrak propolis yang diberikan. Hal ini menunjukkan bahwa pemberian ekstrak propolis konsentrasi 12,5- $200 \mathrm{mM}$ selama 24 jam mampu menghambat proliferasi sel HeLa.

Selanjutnya aktivitas sitotoksisitas ekstrak propolis pada sel HeLa setelah inkubasi 24 jam dinyatakan dengan nilai IC50, yang diperoleh melalui analisis regresi linear antara dosis bahan uji dan persentase viabilitas sel HeLa. Dari analisis regresi linier tersebut diperoleh IC50 ekstrak propolis pada sel HeLa sebesar 70,42 $\pm 1,07 \mu$ / $\mathrm{ml}$, menunjukkan aktivitas sitotoksik yang cukup tinggi jika dibandingkan dengan penelitian syamsudin (2011) di mana nilai IC 50 propolis Sukabumi terhadap sel HeLa sebesar 147,34 \pm 8,9 $\mu / \mathrm{ml}$. Makin kecil nilai IC50 makin aktif propolis sebagai agen antiproliferasi sel kanker.

Induksi apoptosis merupakan salah satu mekanisme yang diajukan sebagai efek terapetik propolis. Penelitian yang dilakukan oleh Motomura et al (2008) mengindikasikan bahwa ekstrak metanol dari propolis $(300 \mu \mathrm{g} / \mathrm{ml}$ dan 500 $\mu \mathrm{g} / \mathrm{ml})$ meningkatkan apoptosis pada sel U937 akibat aktivasi caspase- 3 dan penurunan protein cyclin D1.

Berdasarkan hal ini, dilakukan pengamatan penekanan ekspresi cyclin D1 pada sel HeLa untuk menilai apakah kemampuan propolis dalam menghambat proliferasi sel HeLa pada penelitian ini terkait dengan penekanan ekspresi cyclin D1. Hasil penelitian ini menunjukkan bahwa propolis mampu meningkatkan apoptosis sel HeLa dan juga mengakibatkan penekanan ekspresi $\mathrm{Bcl} 2$ yang sebanding dengan peningkatan konsentrasi yang diberikan. 
Hal ini sejalan dengan penelitian yang dilakukan oleh Motomura et al. yang mengindikasikan bahwa ekstrak metanol dari propolis $(300 \mu \mathrm{g} / \mathrm{ml}$ dan $500 \mu \mathrm{g} / \mathrm{ml})$ meningkatkan apoptosis pada sel U937 akibat aktivasi caspase-3 dan penurunan protein cyclin D1. Over aktivitas caspase-6 yang diinduksi oleh EEP lebih kuat dibandingkan aktivitas caspase- 8 dan caspase-9 yang terinduksi pada sel MCF-7, yang membuktikan adanya keterlibatan jalur caspase intrinsik dari apoptosis dan aktivitas antitumor dari propolis.

Propolis dan senyawanya menginduksi inhibisi proliferasi sel melalui supresi kompleks cyclin dan kinase protein dependen cyclin, dan meningkatkan kadar inhibitor protein seperti Bax pada sel tumor (Sawicka, 2012). Berdasarkan hal ini, dilakukan pengamatan aktivasi Bax untuk menilai apakah aktivasi Bax turut berperan dalam mekanisme penghambatan proliferasi sel HeLa oleh propolis.

Pada penelitian ini terlihat bahwa pemberian ekstrak etanol propolis selama 24 jam meningkatkan aktivasi Bax yang sebanding dengan peningkatan konsentrasi ekstrak etanol propolis yang diberikan. Penelitian ini menunjukkan bahwa propolis mampu menghambat proliferasi sel HeLa dan hal ini kemungkinan terkait dengan kemampuan propolis dalam mengaktivasi Bax.

Hal ini sejalan dengan hasil penelitian oleh Motomura et al. di mana ekstrak metanol dari propolis dengan konsentrasi 100-1.000 $\mu \mathrm{g} / \mathrm{ml}$ secara signifikan mampu menghambat pertumbuhan sel U937 dalam dosis yang telah ditentukan. Analisis flow cytometry mengindikasikan bahwa peningkatan 32,8\% (untuk dosis propolis $300 \mu \mathrm{g} / \mathrm{ml}$ ) dan $37,7 \%$ (untuk dosis propolis $500 \mu \mathrm{g} / \mathrm{ml}$ ) pada jumlah sel U937 dalam fase G2/M, terjadi sebagai akibat dari penurunan ekspresi cyclin A, cyclin B, dan CDK2 dan peningkatan kadar protein p21 dan p27.

\section{SIMPULAN}

Terdapat pengaruh pemberian ekstrak propolis terhadap penekanan ekspresi protein cyclin D1 dan peningkatan ekspresi protein Bax pada kultur sel kanker serviks (sel HeLa).

\section{DAFTAR PUSTAKA}

Alison, M.R. 2001. Cancer. In: Encyclopedia of Life Seciences. Nature Publishing Group. London. United Kingdom.

Ananda, S.K., Tragoolpua, K., Chantawannakul, P., Tragoolpua, Y. 2013. Antioxidant and Anticancer Cell Proliferation of Propolis Extracts from Two Extraction Methods. Asian Pac J Cancer Prev. 14 (11): 6991-6995.

Bankova V. 2007. Propolis of Stingless Bee: A Promising Source of Biologically Active Compounds. Pharmacog Rev. 1: 88-92.

Dash, P. 2003. Apotosis. Basic Medical Sciences [Online] [cited 2013 August 6]: [6 screen]. Available from: URL: http://www. sgul.ac.uk/depts/immunology/-dash

Departemen Kesehatan RI (Depkes RI). 2009. Profil Kesehatan Indonesia 2008. Departemen Kesehatan Republik Indonesia. Jakarta.

Fujimoto, J. 2009. Novel Strategy of Anti-angiogenic Therapy for Uterine Cervical Carcinomas. Anticancer Res. 29: 2665-2669.

Goldie, J.H., 2001. Drug Resisten in Cancer: A Perspective. Cancer and Metastasis Rev. 20:63-68.

Goodwin, E and DiMaio, D. 2000. Repression of Human Papillomavirus Oncogenes in HeLa Cervical Carcinoma Cells Causes the Orderly Reactivation of Dormant Tumor Supressor Pathways. Proc. Natl. Acad. sci. USA. 97(23): 12513-12518.

Hakem, R and Harrington, L. Cell death in Tannock, I.F., Hill, R.P., Bristow, R.G., Harrington, L. 2005. The Basic Science of Oncology. $4^{\text {th }}$ Ed. McGraw-Hill. New York.

Kubina, R., Dzik, A.K., Dziedzic, A., Bielec, B., Wojtczka, R.D., Buldok, R.J., Wysznynska, M., et al. 2015. The Ethanol Extract of Polish Propolis Exhibits Anti-proliferative and/or Pro-apoptotic Effect on HCT 116 Colon Cancer and Me45 Malignant Melanoma Cell in Vitro Conditions. Adv Clin Exp Med. 24(2): 203-212. 
Lin CC, Yu CS, Yang JS, Lu CC, Chiang JH, Lin JP, Kuo CL, Chung JG. 2012. Chrysin, A Natural and Biologically Active Flavonoid, Influences a Murine Leukemia Model in Vivo Through Enhancing Populations of T-and B-cells, and Promoting Macrophage Phagocytosis and NK Cell Cytotoxicity. In Vivo; 26(4): 665-670.

Marcucci MC, Ferreres F, Garc a-Viguera C, Bankova VS, De Castro SL, Dantas AP et al, 2001. Phenolic Compounds from Brazilian Propolis with Pharmacological Activities. J Ethnopharmacol; 74:p.105-12.

Molyneux EM, Rochford R, Griffin B, Newton R, Jackson G, Menon G, Harrison CJ, Israels T, Bailey S. 2012. Burkitt's Lymphoma. Lancet, p 1234-1244.

Motomura, M., Kwon, K.M., Suh, S.J. 2008. Propolis Induces Cell Cycle Arrest and Apoptosis in Human Leukemic U937 Cells through Bcl-2/Bax Regulation. Environ Toxicol Pharmacol. 26:61-67.

Naithani, R., Huma, L.C., Moriarty, R.M., McCormick, D.L., Mehta, R.G. 2008. Comprehensive Review of Cancer Chemopreventive Agentsevaluated in Experimental Carcinogenesis Models and Clinical Trials.Curr Med Chem. 15: 1044-1071.

Nakajima Y, Tsuruma K, Shimazawa M, Mishima S, Hara H. 2009. Comparison of bee Products Based on Assays of Antioxidant Capacities. BMC Complementary and Alternative Medicine, 9:4.

Paulino, N., Abreu, S.R.L., Machodo, G., Silveira, E. 2009. Scientific Evidences to Pharmacological Anticancer Action of Baccharis dracunculifolia Brazilian Propolis. Rev Pesq Inov Farm. 1(1): $15-26$

Salatino A, Teixeira EW, Negri G, and Message D. 2005. Origin and Chemical Variation of Brazilian Propolis. Evid Based Complement Alternat Med, 2(1): p.33-8.

Sawicka D, Car H, Borawska MH, Niklinski J. 2012. The Anticancer Activity of Propolis. Drugs. 50(1): 25-37.

Sharrer, T. 2006. HeLa Herself. The Scientist. 20(7): 22.

Syamsudin, Wiryowidagdo, S., Simanjuntak, P., Heffen, W.L. 2009. Chemical Composition of Propolis from Different Region in Java and their Cytotoxic Activity. AJBB. 5(4): 180-183.

Vatansever, H.S., Sorkun, K. Gurhan, S.I.D., Ozdal-Kurt, F., Turkoz, E., Gencay, O., Salih, B. 2010. Propolis from Turkey Induces Apoptosis through Activating Caspases in Human Breast Carsinoma Cell Lines. Acta Histochem. 112: 546-556.

Watanabe, M.A.E., Amarante, M.K., Conti, B.J., Sforcin, J.M. 2011. Cytotoxic Constituents of Propolis Inducing Anticancer Effect: a Review. JPP. 63: 1378-1386.

Watts and Denise W. 2010. HeLa Cancer Cells Killed Henritta Lacks. Then They Made Her Immortal. The Virginian-Pilot 1:12-14. 